\author{
Adriana KASZUBA-PERZ ${ }^{1}$ \\ Sabina ROKITA ${ }^{2}$
}

\title{
ROLA RACHUNKOWOŚCI W SYSTEMIE INFORMACYJNYM WSPIERAJACYM ZARZĄDZANIE LOGISTYKĄ
}

\begin{abstract}
Konkurencyjność współczesnych przedsiębiorstw coraz częściej budowana jest przez implementację i systematyczne stosowanie nowoczesnych narzędzi zarządzania, w tym również controllingu i rachunkowości zarządczej. Te dwie ostatnie dziedziny, a w zasadzie całe spektrum ich narzędzi w dużym stopniu są wykorzystywane w zintegrowanych systemach zarządzania, tak dzisiaj popularnych zwłaszcza wśród większych przedsiębiorstw. Wprawdzie zarówno praktycy i - co oczywiste - badacze doceniają wciąż ważką rolę rachunkowości wraz z tradycyjnym rachunkiem kosztów jako podstawowego źródła informacji finansowej, jednakże nie sposób prognozować i podejmować decyzję w turbulentnym otoczeniu i budować strategie (zarówno tej krótko- jak i długookresowej) bez zastosowania dodatkowych instrumentów. Dają one przecież nie tylko możliwość głębszej i szerszej analizy kosztów, wyników, identyfikacji ryzyka, oceny gospodarności itd., lecz przede wszystkim ich celem jest ustawiczne wspomaganie procesów decyzyjnych. Niewątpliwie jednym z najbardziej popularnych narzędzi jest budżetowanie. W niniejszym opracowaniu zwrócono uwagę na korzyści wynikające z zastosowania budżetowania w działalności logistycznej, nie tylko dostarcza ono bowiem niezbędnych informacji dla pomiaru dokonań czy wsparcia systemów motywacyjnych, lecz również może być zastosowane szerzej jako instrument planowania i koordynacji - co w logistyce jest niezwykle istotne. Jeśli natomiast - tak jak zaproponowano to w niniejszym artykule - system ewidencji księgowej jest w pełni kompatybilny z architekturą systemu budżetowania, wówczas ta szczególna przydatność budżetu wyrażać się może m.in. poprzez raportowanie i współdziałanie z systemem kontroli.

Słowa kluczowe: rachunkowość zarządcza, budżetowanie, logistyka.
\end{abstract}

\section{WPROWADZENIE}

Rola rachunkowości, zwłaszcza rachunkowości zarządczej, w procesach zarządzania przedsiębiorstwem jest bezsprzecznie nie do przecenienia. Ponadto instrumentarium to wydaje się coraz bardziej uniwersalne, ciągle rozwijające się narzędzia rachunkowości coraz częściej są powiązane $\mathrm{z}$ takimi dziedzinami zarządzania, które dotychczas wydawały się wyłącznie domeną inżynierów czy logistyków. Bez względu na wielkość oraz rodzaj prowadzonej działalności gospodarczej działalność logistyczna, rozumiana jako procesy planowania, a następnie przepływu zapasów: materiałów, towarów, produkcji w toku i produktów pracy, będzie w mniejszym lub większym stopniu stanowić przedmiot zainteresowania właścicieli i zarządu przedsiębiorstw. Doceniając znaczenie tej dziedziny zarządzania w kontekście

${ }^{1}$ Dr inż. Adriana Kaszuba Perz, Zakład Finansów i Rachunkowości, Politechnika Rzeszowska im. I. Łukasiewicza, ul. Powstańców Warszawy 8, 35-959 Rzeszów, tel. (017) 865-19-14, autor korespondencyjny e-mail: aperz@prz.edu.pl

${ }^{2}$ Dr Sabina Rokita, Zakład Finansów i Rachunkowości, Politechnika Rzeszowska im. I. Łukasiewicza, ul. Powstańców Warszawy 8, 35-959 Rzeszów, tel. (017) 865-19-14. 
chociażby budowania konkurencyjności przedsiębiorstwa, warto podkreślić rolę wybranych narzędzi rachunkowości i controllingu wspomagających system pomiaru i analizy efektywności działań logistyki. W niniejszym opracowaniu podjęto zatem próbę prezentacji zaleceń dla przedsiębiorstw w zakresie rachunkowości działalności logistycznej - $\mathrm{z}$ wyłączeniem jednakże przedsiębiorstw o profilu skoncentrowanym wyłącznie na świadczeniu usług logistycznych.

\section{ZARZAZDZANIE DZIAŁALNOŚCIĄ LOGISTYCZNĄ W} PRZEDSIĘBIORSTWIE A POTRZEBY INFORMACYJNE

W literaturze przedmiotu pojęcie logistyki często jest powiązane $\mathrm{z}$ ideą zarządzania procesowego, ponieważ aktywności przedsiębiorstwa związane zarówno z planowaniem i realizacją zamówień i samym zarządzaniem materiałami, towarami czy wyrobami gotowymi, jak również produkcją $\mathrm{w}$ toku, są często tak pojmowane. Działania logistyczne zatem obejmują wiele zadań zachodzących w podmiocie: począwszy od etapu prognozowania sprzedaży, a skończywszy na zabezpieczeniu opakowań, składowaniu i transporcie produktów gotowych. Tak definiują logistykę między innymi John J. Coyle, Edward J. Bardi i John C. Langrey $\mathrm{Jr}^{3}$

Działalność logistyczna występuje zatem w każdym przedsiębiorstwie, bez względu na profil jego działalności (usługowy, handlowy, produkcyjny), chociaż od profilu i wielkości tej działalności zależeć będą zakres i rozmiar działań logistycznych. Wychodząc od definicji i funkcji logistyki w przedsiębiorstwie, z łatwością można sobie wyobrazić liczbę zdarzeń i danych powiązanych ze sobą, które muszą być przekazywane między poszczególnymi komórkami organizacyjnymi, a które dotyczą procesów logistycznych. Niewątpliwie już sama ich liczba, nie wspominając o stopniu skomplikowania (ten może być bowiem uwarunkowany specyfiką i wielkością przedsiębiorstwa), wymusza na zarządzających implementację systemu wspomagającego przepływ informacji i ich przetwarzanie $\mathrm{w}$ odpowiednie raporty. Wiele przedsiębiorstw w ramach Zintegrowanych Systemów Zarządzania ma moduły odpowiadające wymaganiom logistyki. Jednakże w przypadku małych i średnich przedsiębiorstw nakłady na wdrożenie tak dużego systemu informatycznego stanowią istotną barierę jego wdrożenia. Warto zaznaczyć, że w mniejszych przedsiębiorstwach stosowane są najczęściej jedynie podstawowe systemy finansowo-księgowe. Zatem warto się w tym miejscu zastanowić, czy jest możliwe, aby w oparciu na księgowości oraz prostych narzędziach rachunkowości zarządczej zbudować namiastkę systemu informacyjnego, który usprawni, zwiększy skuteczność i efektywność procesów logistycznych w przedsiębiorstwie? W dalszej części niniejszego opracowania podjęto próbę odpowiedzi na to pytanie.

\section{RACHUNKOWOŚĆ JAKO ŹRÓDŁO INFORMACJI FINANSOWYCH O DZIALALNOŚCI LOGISTYCZNEJ}

Według Edwarda Nowaka rachunkowość powinna dostarczać informacji ekonomicznie użytecznych, czyli umożliwiających ich użytkownikom dokonanie oceny kształtowania się tych zjawisk i procesów, które znajdują się pod ich obserwacją i kontrolą jak również rozróżnienie alternatywnych wariantów działania oraz wybór wariantu najlepszego w danych warunkach. Wtedy informacje wspomagają odbiorców w dwóch ważnych działaniach:

\footnotetext{
${ }^{3}$ J.J. Coyle, E.J. Bardi, J.C. Langrey Jr, Zarzqdzanie Logistyczne, Polskie Wydawnictwo Ekonomiczne, Warszawa 2002, s. 51-52
} 
- w analizie działalności przedsiębiorstwa prowadzonej w celu oceny jego sytuacji ekonomiczno-finansowej,

- w podejmowaniu racjonalnych decyzji ekonomicznych zarówno przez jednostki z przedsiębiorstwa, jak i z otoczenia przedsiębiorstwa ${ }^{4}$.

Aby rachunkowość mogła sprostać wymogowi generowania informacji użytecznych, musi być postrzegana jako całościowy i zwarty system ciagłego, systematycznego gromadzenia i przetwarzania danych oraz prezentacji informacji ekonomiczno-finansowych. W systemie tym wykorzystuje się określone metody, reguły postępowania, urządzenia ewidencyjne i środki techniczne umożliwiające rejestrację stanu i zmiany zasobów majątkowych jednostki, źródeł jego finansowania (pochodzenia), dokonywanych operacji gospodarczych i wyników działalności ${ }^{5}$.

W ramach zarządzania logistycznego w literaturze i w praktyce wyodrębnia się wiele podobszarów - ich liczba jest uzależniona od potrzeb informacyjnych i analitycznych. Najczęściej wyodrębnia się: magazynowanie wraz z kontrolą zapasów, zarządzanie zleceniami, zamówieniami, transport i administrowanie samą logistyką ${ }^{6}$. Rachunkowość natomiast jest systemem informacyjnym w zasadzie obejmującej większość procesów wewnętrznych w przedsiębiorstwie. Zatem można przyjąć, że istnieje możliwość takiego dostosowania planu kont (zwłaszcza na poziomie kosztów, ale nie tylko), który uwzględniałby pomiar procesów w zakresie logistyki. Wprawdzie tradycyjna rachunkowość pozwala na dokonywanie analiz w ramach poszczególnych kategorii będących przedmiotem zainteresowania logistyki (zarządzanie majątkiem, zapasami, pomiar i analiza kosztów), jednakże dla celów decyzyjnych, a zwłaszcza wyznaczania wskaźników oceniających efektywność i jakość działań logistycznych, może się okazać niewystarczająca. Niezwykle istotnym $\mathrm{z}$ tego powodu staje się zatem dobrze skonstruowany system informacyjny obejmujący wszystkie aktywności podmiotu, nie tylko w wymiarze wartościowym i ilościowym, lecz także jakościowym. Dlatego też coraz większym zainteresowaniem cieszy się controlling logistyczny. Jakiekolwiek rozwiązanie wspomagające działalność logistyczną przyjąć, system rachunkowości wydaje się niezastąpiony w dostarczaniu podstawowych danych. Zbiory kont syntetycznych $\mathrm{z}$ dostosowanymi do potrzeb informacyjnych kontami analitycznymi pozwolą na identyfikację źródłowych danych, które w kolejnych etapach będą odpowiednio przetwarzane przy wykorzystaniu narzędzi rachunkowości zarządczej i controllingu.

\section{RACHUNEK KOSZTÓW A INFORMACJE O KOSZTACH DZIAŁALNOŚCI LOGISTYCZNEJ}

Ze względu na trudne warunki funkcjonowania na rynku jednym $\mathrm{z}$ istotnych aspektów konkurencyjności jest zdolność do efektywnego wykorzystania zasobów, co często przekłada

\footnotetext{
${ }^{4}$ E. Nowak, Rachunkowość zarzqdcza, Wydawnictwo Profesjonalnej Szkoły Biznesu, Kraków 2001, s. 13.

${ }^{5} \mathrm{~K}$. Sawicki, Istota i zasady funkcjonowania rachunkowości, w: Podstawy rachunkowości, red. K. Sawicki, wyd. 5 zm., Polskie Wydawnictwo Ekonomiczne, Warszawa 2005, s. 14.

${ }^{6}$ Zob. szerzej: J. Dobroszek, Pomiar efektywności dokonań działalności logistycznej, [w:] Pomiar i sprawozdawczość dokonań podmiotów gospodarczych, red. A. Szychta i E. Śnieżek, Wydawnictwo Uniwersytetu Łódzkiego, Łódź 2012; P. Blaik, Logistyka: koncepcja zintegrowanego zarzqdzania, PWE Warszawa 2010, oraz M. Man, M. Nowicka-Skowron, Costs related to the functions of company logistics, „Polish Journal of Management” 2010/1.
} 
się na efektywność kosztową rozumianą jako relacja kosztów do uzyskanego efektu, stąd też kadra zarządzająca poszukuje możliwości obniżenia kosztów w każdym obszarze działalności przedsiębiorstwa. Jednym z tych obszarów jest oczywiście logistyka. Warto zaznaczyć, że działania logistyczne pełnią na ogół w przedsiębiorstwach funkcje pomocnicze, których głównym celem jest wspieranie i usprawnianie działalności podstawowej (nie dotyczy to oczywiście przedsiębiorstw świadczących usługi logistyczne). Ma to swoje daleko idące konsekwencje przejawiające się w ,rozproszeniu” działań logistycznych po całym przedsiębiorstwie, co powoduje znaczne trudności w ich jednoznacznej identyfikacji i wydzieleniu kosztów z nimi związanych. Zwraca na to uwagę Krzysztof Ficoń, formułując dwie zasadnicze przyczyny trudności w pozyskiwaniu informacji na temat kosztów działalności logistycznej ${ }^{7}$ :

- ze względu na ograniczoną jedność procesów gospodarczych istnieją ogromne trudności natury formalnej i organizacyjnej na etapie jednoznacznej i w miarę precyzyjnej identyfikacji odrębnej kategorii kosztów odnoszonych wyłącznie do procesów i strumieni logistycznych;

- $\quad$ stosowane systemy klasyfikacji kosztów logistyki są bardzo rozbudowane i pozostają w silnych uwarunkowaniach i wzajemnych zależnościach, co utrudnia ich ścisłe szacowanie.

W literaturze przedmiotu można znaleźć liczne propozycje klasyfikacji kosztów działań logistycznych, ich analizy dokonała między innymi Renata Gmińska ${ }^{8}$.Warto w tym miejscu przytoczyć te najbardziej popularne, w których koszty logistyczne dzielone są na bezpośrednie i pośrednie, stałe i zmienne, materialne i niematerialne, koszty zaopatrzenia produkcji i dystrybucji. Przytacza się również klasyfikacje, które odnoszą się wprost do konkretnych procesów logistycznych, na przykład transportu, dostaw procesów magazynowania itd. Ciekawe podejście prezentuje również Piotr Blaik, który wyodrębnia między innymi koszty rodzajowe, koszty przepływu, faz i miejsc powstawania, koszty relacji z podstawowymi rodzajami procesów logistycznych, koszty zmienności w odniesieniu do wielkości przepływów materiałowych lub zapasów ${ }^{9}$.

W każdym przedsiębiorstwie podstawowym źródłem informacji o kosztach jest rachunek kosztów, który może być rozumiany jako ,zbiór informacji o kosztach działalności jednostki, opracowany według przyjętego modelu dostosowanego do potrzeb informacyjnych wewnętrznych i zewnętrznych odbiorców informacji. Jego celem jest dostarczenie informacji dotyczących podejmowania decyzji zarządczych oraz kontroli realizacji tych decyzji, a także informacji dotyczących wyceny zapasów i pomiaru wyniku finansowego w świetle unormowań prawa bilansowego. Zakres rachunku kosztów obejmuje planowanie, ewidencję, kalkulację i analizę kosztów jednostki" ${ }^{10}$. W takim ujęciu rachunek kosztów będzie obejmował zarówno systematyczny rachunek kosztów będący podsystemem sytemu rachunkowości, jak i

\footnotetext{
${ }^{7}$ K. Ficoń, Logistyka ekonomiczna. Procesy logistyczne, BEL Studio, Warszawa 2008, s. 254, cyt. za: M. Cieciura, H.E. Czaja-Cieszyńska, Konstrukcja systematycznego rachunku kosztów logistyki w kontekście tworzenia wartości przedsiębiorstwa, „Prace Naukowe Uniwersytetu Ekonomicznego we Wrocławiu" 2012/252, s.77.

${ }^{8}$ R. Gmińska, Rachunek kosztów logistyki jako narzędzie zarzq̨ania kosztami, „Prace Naukowe Uniwersytetu Ekonomicznego we Wrocławiu" 2012/252, s.131.

${ }^{9}$ P. Blaik, op. cit.

${ }^{10}$ Rachunek kosztów i rachunkowość zarzqdcza. Pojęcia, problemy, zadania., red. A. Karmańska, Difin, Warszawa 2004, s. 54.
} 
pozaewidencyjne rachunki kosztów, których liczą grupę stanowią tzw. nowoczesne rachunki kosztów.

Szczególnie istotnym reprezentantem systematycznego rachunku kosztów jest rachunek kosztów pełnych, nazywany też sprawozdawczym lub tradycyjnym rachunkiem kosztów, który jest podporządkowany wymogom rachunkowości finansowej. Informacje kosztowe z niego płynące muszą spełniać określone kryteria, dzięki którym możliwe jest prawidłowe sporządzanie sprawozdań finansowych i innych obligatoryjnych rozliczeń. Podstawową klasyfikacją kosztów obowiązujących w tym rachunku jest podział na koszty bezpośrednie i pośrednie (produkcyjne i nieprodukcyjne). Warto w tym miejscu wspomnieć, że koszty działalności logistycznej, klasyfikowane są w tym rachunku w kosztach pośrednich, chyba że działalność logistyczna byłaby działalnością podstawową przedsiębiorstwa, wtedy mogą one znaleźć się również w kosztach bezpośrednich. Ze względu na obwiązujące zasady grupowania kosztów w rachunku kosztów pełnych mogą $\mathrm{z}$ niego zostać wygenerowane informacje o kosztach logistycznych w zasadzie w trzech przekrojach: rodzajowym, podmiotowym, przedmiotowym. Biorąc pod uwagę różnorodność klasyfikacji kosztów logistycznych przedstawionych chociażby w tabeli 1, można stwierdzić, zwykle są to informacje dalece niewystarczające, dlatego w literaturze można spotkać propozycje doskonalenia ewidencji kosztów działalności logistycznej w ramach systematycznego rachunku kosztów poprzez odpowiednią rozbudowę kont syntetycznych i analitycznych, na przykład według faz (faza zaopatrzenia, faza produkcji, faza dystrybucji) i płaszczyzn (płaszczyzna fizycznych przemieszczeń dóbr rzeczowych, płaszczyzna gospodarki magazynowej, płaszczyzna informacji logistycznych) procesów logistycznych ${ }^{11}$. Jednak należy pamiętać, że struktura kont księgowych, klasyfikacja kosztów, dokumentacja operacji gospodarczych i zasady ich ewidencji są budowane w systematycznym rachunku kosztów zawsze przy uwzględnieniu wymogów obowiązującego prawa bilansowego, dlatego często dla zaspokojenia potrzeb informacyjnych kadry zarządzającej o kosztach logistycznych konieczne jest sięganie do możliwości oferowanych przez pozaewidencyjne rachunki kosztów. Konrad Kochański wskazuje na szczególną przydatność wybranych nowoczesnych rachunków kosztów w zarządzaniu logistyką, a mianowicie ${ }^{12}$ :

- rachunek kosztów działań (ABC, activity based costing) - umożliwia ustalenie kosztów logistycznych w przekroju procesów i działań, co powinno przynieść wiele korzyści typowych dla tego go rachunku, czyli możliwość analizy działań logistycznych oraz ich kosztów, doskonalenia działań istotnych, wykrywanie i ewentualna eliminacja działań zbędnych, ustalanie rentowności działalności logistycznej w ustalonych przekrojach, efektywne zarządzanie zasobami wykorzystywanymi w logistyce poprzez adekwatne planowanie i eliminację marnotrawstwa;

- $\quad$ rachunek kosztów cyklu życia (life cycle costing) - umożliwia ocenę zyskowności świadczonych usług logistycznych w całym cyklu ich życia poprzez porównanie przychodów z kosztami - rachunek ten może być szczególnie przydatny w przedsiębiorstwach, których podstawową działalnością jest świadczenie usług logistycznych;

- rachunek kosztów docelowych (target costing) - dzięki ustaleniu docelowej ceny sprzedaży i oczekiwanego poziomu zysku rachunek ten pozwala na wyznaczenie kosztu

\footnotetext{
${ }^{11}$ Więcej na ten temat w M. Cieciura, H.E. Czaja-Cieszyńska, op. cit., s. 77.

${ }^{12}$ Por. K. Kochański, Nowoczesne koncepcje rachunku kosztów i ich przydatność w podejmowaniu decyzji w obszarze logistyki przedsiębiorstwa, „Prace Naukowe Uniwersytetu Ekonomicznego we Wrocławiu" 2012/252, s. 228-234.
} 
docelowego usługi logistycznej, który nie może zostać przekroczony, jeśli ma być osiągnięty wyznaczony cel finansowy (zysk);

- $\quad$ rachunek kosztów ciąłłego doskonalenia (kaizen costing) - polega na ciągłej analizie oraz doskonaleniu procesów, metod, organizacji pracy, którego skutkiem powinna być obniżka kosztów działań logistycznych;

- rachunek kosztów jakości (cost of quality) - pozwala na ustalenie kosztów związanych z zapewnieniem odpowiedniej jakości usług logistycznych oczekiwanej przez klientów - narzędzie szczególnie przydatne w przedsiębiorstwach wykorzystujących zarządzanie przez jakość.

W sytuacji gdy działalność logistyczna jest znacznie rozbudowana, a jej koszty stanowią znaczącą część w strukturze kosztów przedsiębiorstwa, warto rozważyć opracowanie kompleksowego rachunku kosztów logistyki, na którego elementy składają się ${ }^{13}:$

- $\quad$ system ewidencyjny kosztów logistyki - obejmujący zarówno systematyczny rachunek kosztów z odpowiednio rozbudowaną strukturą kont syntetycznych i analitycznych, jak również ewidencję pozabilansową w ramach rachunkowości zarządczej;

- $\quad$ klasyfikacja kosztów logistyki - ściśle dostosowana do potrzeb informacyjnych zarządzania i spójna z systemem ewidencyjnym;

- rozliczanie kosztów logistyki - na nośniki działań, za pomocą kluczy rozliczeniowych ustalanych indywidualnie przez przedsiębiorstwo;

- $\quad$ kalkulacja kosztów logistyki - której wynikiem jest ustalenie kosztu jednostkowego przedmiotu kalkulacji przy wykorzystaniu kalkulacji tradycyjnych bądź opartych na nowoczesnych rachunkach kosztów;

- $\quad$ system sprawozdawczy kosztów logistyki - generowane raporty powinny ściśle odpowiadać potrzebom zarządzania;

- $\quad$ analiza kosztów logistyki - między innymi pozwala na ocenę struktury kształtowania się kosztów działalności logistycznej oraz ich dynamiki w czasie.

Odpowiednio opracowany i wdrożony w przedsiębiorstwie rachunek kosztów logistyki powinien umożliwić ${ }^{14}:$

- „badanie kosztów logistyki i ich prognozowanie,

- dokonanie oceny wpływu kosztów logistyki na wynik finansowy przedsiębiorstwa,

- kontrolę poziomu kosztów logistyki,

- ocenę osiaggniętych celów, zadań, planów oraz budżetów w obszarze logistyki przez poszczególne ośrodki odpowiedzialności,

- wybór optymalnego wariantu działania logistyki oraz struktury zasobów niezbędnych do jego realizacji,

- redukcję kosztów logistyki”.

Oczywiście należy pamiętać, aby rachunek kosztów logistyki ściśle odpowiadał potrzebom zarządzania, a zaproponowane konkretne rozwiązania w tym zakresie powinny być na tyle spójne i właściwie wkomponowanie w system rachunku kosztów przedsiębiorstwa, by ich wykorzystanie w praktyce przyniosło wymierne korzyści.

\footnotetext{
${ }^{13}$ R. Gmińska, op. cit., s. 132.

${ }^{14}$ Ibidem, s. 134.
} 


\section{BUDŻET JAKO NARZĘDZIE RACHUNKOWOŚCI ZARZĄDCZEJ WSPIERAJĄCE ZARZĄDZANIE OPERACYJNE DZIALALNOŚCIĄ LOGISTYCZNA}

Jednym ze skuteczniejszych narzędzi planowania operacyjnego w osiaganiu założonych celów jest budżet. Budżet to wyrażony w jednostkach ilościowych i wartościowych plan przydzielony określonej jednostce decyzyjnej do realizacji w danym okresie obrachunkowym, którym może być rok kalendarzowy bądź okres wynikający z cyklu realizacji zadania ${ }^{15}$. Zarówno metody sporządzania budżetów, jak i sam proces budżetowania w dużej mierze zależą od rodzaju prowadzonej działalności i tylko wtedy, gdy są one dostosowane do jej charakteru, mają szanse przynieść zamierzony efekt.

Budżetowanie w obszarze kosztów działalności logistycznej może przynieść przedsiębiorstwu wiele korzyści, wśród których warto wymienic ${ }^{16}:$ :

- mobilizowanie do okresowego planowania kosztów działalności logistycznej w ustalonym przez przedsiębiorstwo układzie;

- umacnianie koordynacji, współpracy i komunikowania;

- ułatwianie kwantyfikacji opisowych zamierzeń i celów;

- dostarczanie podstaw do kontroli i oceny dokonań;

- dostarczanie danych do opracowania systemów motywacyjnych w przedsiębiorstwie;

- kreowanie świadomości głównie w zakresie kosztów prowadzonej działalności logistycznej.

Szczególna przydatność budżetów w zarządzaniu działalnością logistyczną ujawnia się na etapie kontroli wykonania budżetu, zwłaszcza gdy zapewniono spójność układu budżetu z układem ewidencyjnym kosztów logistycznych, co zapewnia łatwość w generowaniu odpowiednich raportów (przykładowy raport zaprezentowano w tabeli 1) oraz ich późniejszą analizę.

Istotne znaczenie spójności pomiędzy systemem sprawozdawczości a planowaniem potwierdzają badania wśród grupy przedsiębiorstw PKS w województwie dolnośląskim przeprowadzone przez Agnieszkę Tubis. Badanie te wykazały, że „obowiązujące systemy sprawozdawczości dotyczą wyłącznie lub przede wszystkim kwestii finansowych, a przedsiębiorstwa te rzadko wykorzystują wskaźniki i analizy logistyczne do czuwania nad poprawnością realizowanych procesów [...] sytuacja ta nie zawsze wynika z niedostatku wiedzy w tym obszarze. Podstawowej przyczyny należy doszukiwać się raczej w braku zintegrowanego systemu koordynującego planowanie i kontrolę w obszarze logistyki, połączonego z kompleksowym systemem informacyjnym wspierającym proces podejmowania decyzji logistycznych",17.

\footnotetext{
${ }^{15}$ E. Nowak, Budżetowanie kosztów w zarzqdzaniu przedsiębiorstwem, [w:] Budżetowanie kosztów, red. E. Nowak, ODDK, Gdańsk 1998, s. 8.

${ }^{16}$ Por. A. Dyduch, Budżetowanie kosztów w Państwowym Gospodarstwie Leśnym Lasy Państwowe, „Prace Naukowe Uniwersytetu Ekonomicznego we Wrocławiu” 2012/252, s. 90.

${ }_{17}^{17}$ A. Tubis, Controlling logistyczny w przedsiębiorstwach przewozów pasażerskich Grupy PKS, „Prace Naukowe Uniwersytetu Ekonomicznego we Wrocławiu” 2012/251, s. 493.
} 
Tabela 1. Raport z realizacji budżetu kosztów działalności logistycznej według faz i kosztów rodzajowych na dowolny dzień kontroli

\begin{tabular}{|c|c|c|l|l|l|}
\hline $\begin{array}{c}\text { Działalności } \\
\text { logistyczna }\end{array}$ & $\begin{array}{c}\text { Koszty } \\
\text { planowane } \\
\text { do dnia }\end{array}$ & $\begin{array}{c}\text { Koszty rzeczywiste } \\
\text { do dnia kontroli }\end{array}$ & Odchylenie & $\begin{array}{c}\text { Całkowite koszty } \\
\text { planowane }\end{array}$ & $\begin{array}{c}\text { Wykonanie } \\
\text { planu (\%) }\end{array}$ \\
\hline $\begin{array}{c}\text { Faza } \\
\text { zaopatrzenia, } \\
\text { tym: }\end{array}$ & & & & & \\
\hline Amortyzacja & & & & & \\
\hline $\begin{array}{c}\text { Zużycie } \\
\text { materiałów }\end{array}$ & & & & & \\
\hline$\ldots$ & & & & & \\
\hline $\begin{array}{c}\text { Faza produkcji, } \\
\text { w tym: }\end{array}$ & & & & & \\
\hline Amortyzacja & & & & & \\
\hline $\begin{array}{c}\text { Zużycie } \\
\text { materiałów }\end{array}$ & & & & & \\
\hline$\ldots$ & & & & & \\
\hline $\begin{array}{c}\text { Faza } \\
\text { dystrybucji, } \\
\text { tym: }\end{array}$ & & & & & \\
\hline Amortyzacja & & & & & \\
\hline $\begin{array}{c}\text { Zużycie } \\
\text { materiałów }\end{array}$ & & & & & \\
\hline$\ldots$ & & & & & \\
\hline Razem & & & & & \\
\hline
\end{tabular}

Źródło: opracowanie własne.

\section{PODSUMOWANIE}

Biorąc pod uwagę, że działalność logistyczna najczęściej jest postrzegana przez pryzmat procesów, można stwierdzić, że problematyka pomiaru i analizy tychże będzie mieć kluczowe znaczenie. W literaturze wielu badaczy wskazuje różnorodne rozwiązania związane z oceną dokonań, wykorzystując koncepcję controllingu logistycznego ${ }^{18}$, a przy tym kreując systemy wskaźników, a nawet stosując ideę strategicznej karty wyników. Takie rozwiązania są oczywiście użyteczne i ich wdrożenie zupełnie uzasadnione, jednakże należy zaznaczyć, że nakłady na opracowanie tak rozbudowanego systemu mogą być zbyt wysokie dla mniejszych podmiotów - nawet w świetle potencjalnych korzyści przejawiających się na przykład w postaci zwiększenia skuteczności działania czy skrócenia czasu przebiegu procesów. Wobec czego w niniejszym opracowaniu zaproponowano bardziej klasyczne podejście na podstawie koncepcji budżetowania i kosztów ujmowanych według tradycyjnego rachunku kosztów. Wyodrębniając kolejne fazy działalności logistycznej w danym przedsiębiorstwie, jednocześnie identyfikuje się dla nich koszty według rodzaju (a więc w tradycyjnym podejściu, z wykorzystaniem klasycznej ewidencji księgowej). Oczywiście wymaga to odpowiedniego dostosowania planu kont (syntetyki i analityki), aby takie ujęcie kosztów dla potrzeb budżetowania było możliwe, jednakże nie wymaga to implementacji odrębnych systemów.

\footnotetext{
${ }^{18}$ Zob. m.in. B. Sliwczyński, Controlliong w zarzqdzaniu logistyka, Wyższa Szkoła Logistyki,
} Poznań 2007, oraz P. Blaik, op. cit. 
Samo budżetowanie jest dość powszechnie znanym i stosowanym narzędziem, więc dostosowanie jego procedur i zasad do specyfiki przedsiębiorstw i indywidualnych wymagań przedsiębiorcy (zarządzających) nie będzie trudne. $\mathrm{Z}$ całą pewnością budżetowanie daje możliwość pomiaru i oceny efektywności, gospodarności oraz skuteczności wielu obszarów działalności logistycznej. W kontekście funkcji zarządzania logistycznego i jego roli w kształtowaniu wyników i wizerunku podmiotu gospodarczego zastosowanie narzędzi rachunkowości wspomagających te procesy jest niezwykle istotne, podejście zaproponowane w niniejszym opracowaniu zaś wydaje się w dużym stopniu uniwersalne, co z pewnością umożliwi wykorzystanie również przez mniejsze przedsiębiorstwa, zwłaszcza że nie są konieczne wysokie nakłady na jego implementację.

\section{LITERATURA}

[1] Cieciura M., Czaja-Cieszyńska H.E., Konstrukcja systematycznego rachunku kosztów logistyki w kontekście tworzenia wartości przedsiębiorstwa, „Prace Naukowe Uniwersytetu Ekonomicznego we Wrocławiu” 2012/252.

[2] Coyle J.J., Bardi E.J., Langrey Jr J.C., Zarzqdzanie Logistyczne, Polskie Wydawnictwo Ekonomiczne, Warszawa 2002.

[3] Dyduch A., Budżetowanie kosztów w Państwowym Gospodarstwie Leśnym Lasy Państwowe, „Prace Naukowe Uniwersytetu Ekonomicznego we Wrocławiu" 2012/252.

[4] Ficoń K., Logistyka ekonomiczna. Procesy logistyczne, BEL Studio, Warszawa 2008.

[5] Gmińska R., Rachunek kosztów logistyki jako narzędzie zarzqdzania kosztami, „Prace Naukowe Uniwersytetu Ekonomicznego we Wrocławiu” $2012 / 252$.

[6] Kochański K., Nowoczesne koncepcje rachunku kosztów i ich przydatność w podejmowaniu decyzji w obszarze logistyki przedsiębiorstwa, „Prace naukowe Uniwersytetu Ekonomicznego we Wrocławiu" 2012/252.

[7] Man M., Nowicka-Skowron M., Costs related to the functions of company logistics, „Polish Journal of Management” 2010/1.

[8] Nowak E., Budżetowanie kosztów w zarzqdzaniu przedsiębiorstwem, [w:] red. E. Nowak, Budżetowanie kosztów, ODDK, Gdańsk 1998.

[9] Nowak E., Rachunkowość zarzqdcza, Wydawnictwo Profesjonalnej Szkoły Biznesu, Kraków 2001.

[10] Rachunek kosztów i rachunkowość zarządcza. Pojęcia, problemy, zadania, red. A. Karmańska, Difin, Warszawa 2004.

[11] Tubis A., Controlling logistyczny $w$ przedsiębiorstwach przewozów pasażerskich Grupy PKS, ,Prace Naukowe Uniwersytetu Ekonomicznego we Wrocławiu" 2012/251.

[12] Sawicki K., Istota i zasady funkcjonowania rachunkowości, [w:] red. K. Sawicki, Podstawy rachunkowości, wyd. 5 zm., Polskie Wydawnictwo Ekonomiczne, Warszawa 2005.

[13] Śliwczyński B., Controlliong $w$ zarządzaniu logistyka, Wyższa Szkoła Logistyki, Poznań 2007. 


\section{ROLE OF ACCOUNTING IN INFORMATION SYSTEM SUPPORTING}

\section{LOGISTICS MANAGEMENT}

The competitiveness of modern enterprises are nowadays often built through the implementation and systematic application of modern management tools, including controlling and management accounting. These latter two areas and in fact the whole spectrum of tools which are used heavily in integrated management systems which are popular today, especially among larger companies. Although both practitioners and researchers obviously still appreciate the important role of accounting together with the traditional cost accounting as a primary source of financial information, but it is impossible to predict and decide in a turbulent environment and build strategies (both in the short and long term) without the use of additional instruments. They give the opportunity to both deeper and more extensive analysis of the cost, performance, risk identification, assessment of the efficiency etc., but above all, their purpose is to support the decision making process. Undoubtedly one of the most popular tools is budgeting. In this paper a number of benefits from the fact the use of budgeting in logistics activities is identified. Budgeting process in logistic not only provides the necessary information to measure the overall performance but also can support motivation systems. It can also be used more widely as a tool for planning and coordination - which is extremely important logistics. If, however - as proposed in this article - accounting system is fully compatible with the architecture of the system of budgeting - the usefulness of this particular budget can be expressed, inter alia, through reporting and interaction with the control system.

Keywords: management accounting, budgeting, logistics.

DOI:10.7862/rz.2014.hss.56

Przesłano do redakcji: październik 2014

Przyjęto do druku: grudzień 2014 